\title{
密詰め砂地盤における円形および正方形 アンカー基礎の引抜きについて
}

\author{
酒井 俊典 ${ }^{1} \cdot$ 田中 忠次 $^{2}$ \\ ${ }^{1}$ 正会員 三重大学大学院教授 大学院生物資源学研究科（广 514-8507 三重県津市栗真町屋町 1577） \\ E-mail: sakai@bio.mie-u.ac.jp \\ 2 正会員 東京大学大学院教授 大学院農学生命科学研究科 ( $\mathrm{T} 113-8657$ 東京都文京区弥生 1-1-1)
}

E-mail: atana@mail.ecc.u-tokyo.ac.jp

\begin{abstract}
円形アンカー基礎および正方形アンカー基礎を対象に, 基礎形状が引抜き抵抗およびせん断帯の発達に及ぼ す影響について, モデル実験および三次元弾塑性有限要素解析から検討を行った。モデル実験は, 地盤試料に 豊浦砂を使用し, 密詰め状態で $h / D(h$ : 地盤高さ, $D$ : 基礎幅) を 2 として行った. 有限要素解析は, 非関連 流れ則を適用し，せん断帯・ひずみ軟化を考慮に入れた三次元弾塑性有限要素解析を使用した. その結果，本 解析は実験を再現でき, 同一 $D$ に対する荷重值は正方形アンカー基礎で大きく, 無次元荷重值は円形アンカー 基礎で大きかった。 また，両アンカー基礎とも $D$ の増加に伴い無次元荷重值は低下し，スケール効果が認めら れたものの，両アンカー基礎のスケール効果の程度に大きな差は見られなかった.
\end{abstract}

Key Words : anchor foundation, sand, dense condition, scale effect, model test, 3D finite element analysis

\section{1. はじめに}

アンカー基礎の引抜きに関する研究は，鉄塔，橋梁， 各種構造物の基礎等各方面に広く利用されるため, 数 多くの研究が行われてきている．現在までの古典的な これらの研究は, 平面ひずみ問題あるいは軸対象問題 を対象に，実験により基礎の引抜きに伴う破壊面形状 の観察を行い, この観察結果を基に種々の安定解析法 の提案を行ったものであった $1,2,3), 4)$. しかし, 安定解 析に基づく解析は, 剛塑性論を基本とし, 実際の土で 見られるひずみ軟化を伴う弾塑性現象を考慮できない 上，地盤の進行性破壞も取り扱えず，問題が多いと考え られている.このため現在, 各種弾塑性構成モデルに 基づいた有限要素解析による数值解析が提案されてい る5),6),7). このうち, Rowe \& Davis ${ }^{8)}$ は, 砂地盤におけ る基礎の引抜き抵抗力の検討を, モール・クーロンモ デルを用いた弾塑性モデルに基づく有限要素解析によ り行ったものの, この解析では, 実際の地盤で見られ る進行性破壊現象を十分考慮できていない。これに対 し, Sakai \& Tanaka ${ }^{9}$ は, 地盤の進行性破壊を評価でき るせん断帯・ひずみ軟化を考慮に入れた弾塑性有限要 素解析を, 水平 2 層地盤の円形基礎の引抜き問題に適 用し, 解析が精度良く基礎の引抜き問題を再現できる ことを示した。 また, 岡安ら ${ }^{10)}$ は, 下負荷面モデルに基 づく有限要素解析の妥当性の検討を, Sakai \& Tanaka ${ }^{11)}$ が行った円形基礎の引抜き実験結果との比較により行 い，この解析により良い結果が得られることを示した.
このように, 現在までの有限要素解析による基礎の引 抜きに関する研究は，二次元問題を中心とした検討が 主に行われてきている。しかし, 基礎の形状効果ある いは傾斜地盤での引抜き抵抗等に対する検討を行う場 合, 三次元問題に対する評価が必要となる. 三次元問 題に対して, Ovesen ${ }^{12}$ は, 遠心力載荷実験により円形 基礎および正方形基礎の引抜き実験を行い, 両者の引 抜き抵抗力の違いを評価するとともに，スケール効果 の検討を行った。 また, Meyerhof \& Adams $\left.{ }^{13}\right)$ は, 平面 ひずみ問題であるトラップドア受働状態を基本に, 形 状係数を考慮した矩形基礎, 円形基礎の引抜き抵抗力 の算定式を提案した．ところで，三次元問題を対象に した有限要素解析に対し, 酒井ら ${ }^{14)}$ は, 傾斜地盤におけ る基礎の引抜き抵抗力および破壊面形状について, せ ん断帯・ひずみ軟化を考慮に入れた三次元弾塑性有限 要素解析により検討を行い, この解析が実験結果をよ く再現できることを示した。また，池田ら $\left.{ }^{15}\right)$ は, 傾斜 地盤における逆 $\mathrm{T}$ 型基礎の引揚げに対し, 有限変形理 論と陰解法応力積分アルゴリズムに基づく三次元弾塑 性有限要素を実施し, 酒井らの実駼結果との比較を行 うとともに，この解析が良好にモデル化できることを 述べた。このように, アンカー基礎の三次元評価に関 し，現在まで傾斜地盤に対する検討は行われているも のの, アンカー形状を考慮した検討は十分行われてい ない，そこで本研究では， 円形基礎，正方形基礎を対 象に, アンカー基礎形状が, 引抜き抵抗力, せん断帯 発達形状，およびスケール効果に及ぼす影響について, 
モデル実験およびせん断帯・ひずみ軟化を考慮した三 次元弾塑性有限要素解析の両者から検討を行った.

\section{2. 実験方法}

図-1に実験に使用した装置を示す。実験は，直径 $59 \mathrm{~cm}$ の硬質塩化ビニール製円形モールドの中央にア ンカー基礎を設置し, 地盤作製を行った後, アンカー 基礎を引抜き装置によって垂直に引抜くことで行った. 実験に使用したアンカー基礎の形状は，円形および正 方形の 2 種類で, 両アンカー基礎のプレート厚さおよ び軸径はそれぞれ $0.5 \mathrm{~cm}$ で，材質は鋼製である。また， 両アンカー基礎の基礎幅 $(D)$ (直径および一辺の長さ) は，スケール効果の検討を行うため， $D=3 \mathrm{~cm}, 5 \mathrm{~cm}$, $7 \mathrm{~cm}, 10 \mathrm{~cm} の 4$ 種類を使用した。地盤試料には豊浦砂 を使用し，地盤作製は比較的均一な地盤作製が行える空 中落下法を用いた。作製地盤は相対密度 $\left(D_{r}\right)$ が $95 \%$ の 密詰めとし, 地盤高さ $(h)$ と $D$ との比は 2 とした。な お，ここでの $h$ は，地盤底面から地表面までの高さで ある. 基礎の引抜き速度は $0.03 \mathrm{~mm} / \mathrm{min}$ とし, 基礎引 抜きに伴う荷重変化は基礎の軸と接続した荷重変換器 により, 変位変化は基礎の軸上部に設置した変位変換 器により測定を行った。

有限要素解析は，田中ら ${ }^{16)}$ が提案した非関連流れ則 を適用し, せん断帯・ひずみ軟化を考慮に入れた三次 元弾塑性有限要素解析を用いた。 せん断帯を含むひず み軟化構成式における, せん断帯の効果は, 要素の体 積 $F_{e}$ と要素内のせん断帯部分の体積 $F_{b}$ との体積比 $S$ で定義した。

$$
S=\frac{F_{b}}{F_{e}}
$$

全ひずみ増分 $d \varepsilon$ は, 弾性ひずみ増分 $d \varepsilon^{e}$ と, 塑性ひ

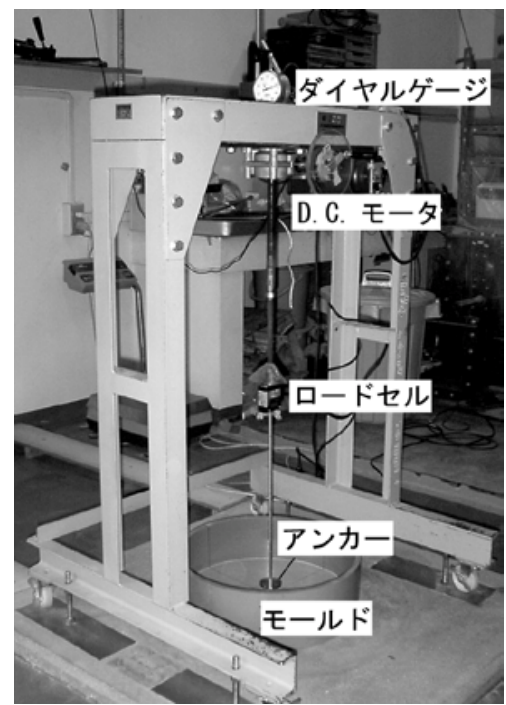

図-1 実験装置
ずタ増分 $d \varepsilon^{p}$ の和で表され，このうち塑性変形するの はせん断帯内部だけであるため,

$$
d \varepsilon=d \varepsilon^{e}+S d \varepsilon^{p}
$$

と考える.

降伏関数 $f$ および塑性ポテンシャル関数 $\Psi$ が, 応力 $\sigma$ および単一の軟化パラメータ $\kappa$ で与えられると考える.

$$
\begin{aligned}
& f(\sigma, \kappa)=0 \\
& \Psi(\sigma, \kappa)=0
\end{aligned}
$$

塑性ひずみ増分 $d \varepsilon^{p}$ は,

$$
d \varepsilon^{P}=\lambda \frac{\partial \Psi}{\partial \sigma}
$$

で決定される.

ここで, $d f=0$ より,

$$
\begin{gathered}
\frac{\partial f}{\partial \sigma} d \sigma+\frac{\partial f}{\partial \kappa} d \kappa=0 \\
\frac{\partial f}{\partial \sigma} d \sigma-A \lambda=0 \\
A=-\frac{1}{\lambda} \frac{\partial f}{\partial \kappa} d \kappa
\end{gathered}
$$

が導かれる。

ここで,

$$
\begin{aligned}
& a=\frac{\partial f}{\partial \sigma} \\
& b=\frac{\partial \Psi}{\partial \sigma}
\end{aligned}
$$

とし，弾性マトリックスを $D$ とすると，式 (2) は,

$$
d \varepsilon=D^{-1} d \sigma+S \lambda b
$$

で表される。

式(7)の両辺に $a^{T} D$ を乗じて $\lambda$ を求めると,

$$
\lambda=\frac{a^{T} D d \varepsilon}{A+S a^{T} D b}
$$

となる、

また，式 (7)の両辺に $D$ を乗じると，

$$
D d \varepsilon=d \sigma+s \lambda D b=d \sigma+\frac{S D b a^{T} D d \varepsilon}{A+S a^{T} D b}
$$

となり，せん断帯を含む応力ーひずみ関係は，

$$
d \sigma=\left(D-\frac{S D b a^{T} D}{A+S a^{T} D b}\right) d \varepsilon
$$

で与えられる。

本解析の降伏関数には，Mohr-Coulomb モデルを，塑 性ポテンシャル関数には Drucker-Prager モデルを採用 し, $f(\sigma, \kappa), \Psi(\sigma, \kappa)$ は,

$$
\begin{gathered}
f=\frac{\sqrt{J_{2}}}{g(\theta)}+3 \alpha(\kappa) \sigma_{m}-\gamma(\kappa)=0 \\
\Psi=\sqrt{J_{2}}+3 \alpha^{\prime}(\kappa) \sigma_{m}-\gamma^{\prime}(\kappa)=0 \\
\kappa=\int d \bar{\varepsilon}^{P} \\
\left(d \bar{\varepsilon}^{P}\right)^{2}=2\left\{\left(d \varepsilon_{x}^{P}\right)^{2}+\left(d \varepsilon_{y}^{P}\right)^{2}+\left(d \varepsilon_{z}^{P}\right)^{2}\right\}+\left(d \gamma_{x y}^{P}\right)^{2} \\
+\left(d \gamma_{y z}^{P}\right)^{2}+\left(d \gamma_{x z}^{P}\right)^{2}
\end{gathered}
$$




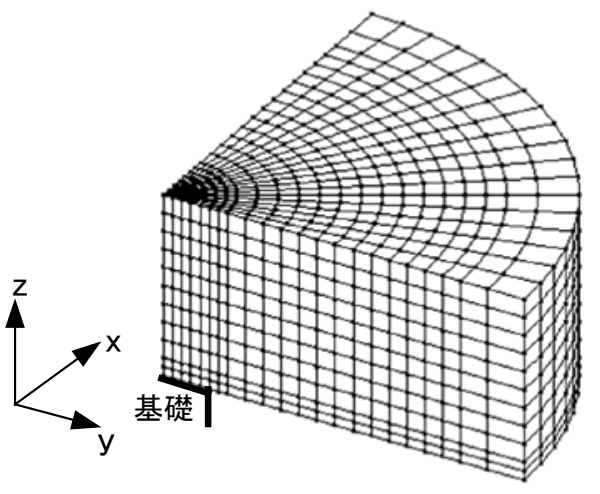

(a) 円形基礎

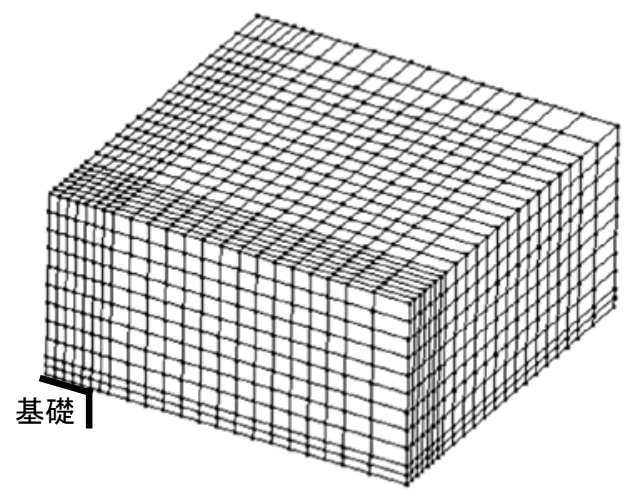

(b) 正方形基礎

図-2 有限要素メッシュ

で与えられる，ここで， $\sigma_{m}$ は平均応力， $J_{2}$ は偏差応力 の 2 次不変量である.

Mohr-Coulomb モデルの場合, $g(\theta)$ は,

$$
\begin{gathered}
g(\theta)=\frac{3-\sin \phi_{\mathrm{mob}}}{2 \sqrt{3} \cos \theta-2 \sin \theta \sin \phi_{\mathrm{mob}}} \\
\sin 3 \theta=-\frac{3 \sqrt{3} J_{3}}{2 J_{2}^{1.5}}
\end{gathered}
$$

で与えられる，ここで， $\phi_{\mathrm{mob}}$ は動員された内部摩擦角， $J_{3}$ は偏差応力の 3 次不変量である.

$\alpha(\kappa), \gamma(\kappa)$ は，それぞれ動員された内部摩擦角および 粘着力の成分と関係づけられ, 本研究では砂地盤を対 象とするため, 粘着力成分に関係する $\gamma(\kappa)$ は無視する.

$\alpha(\kappa)$ は, ピーク強度の $\alpha_{p}$ から残留強度の $\alpha_{r}$ まで低 下するとして

$$
\begin{gathered}
\alpha(\kappa)=\alpha_{p}+\frac{\alpha_{1} \kappa}{B+\kappa} \\
\alpha_{1}=-\left(\alpha_{p}-\alpha_{r}\right) \\
\alpha_{p}=\frac{2 \sin \phi_{p}}{\sqrt{3}\left(3-\sin \phi_{p}\right)} \\
\alpha_{r}=\frac{2 \sin \phi_{r}}{\sqrt{3}\left(3-\sin \phi_{r}\right)}
\end{gathered}
$$

とする。

塑性ポテンシャルにおける $\alpha^{\prime}(\kappa)$ は, ピーク強度に対 応するダイレイタンシーを規定する $\alpha_{p}^{\prime}$ から残留状態の 0 まで変化するとし，

$$
\begin{gathered}
\alpha^{\prime}(\kappa)=\alpha_{p}^{\prime}\left(1-\frac{\kappa}{C+\kappa}\right) \\
\alpha_{p}^{\prime}=\frac{\tan \psi_{0}}{\sqrt{9+12 \tan ^{2} \psi_{0}}}
\end{gathered}
$$

とする。

以上，本構成モデルは，ピーク強度までが弾性であ り，その後双曲線的にひずみ軟化する比較的単純なモ デルである。

$\alpha(\kappa), \alpha^{\prime}(\kappa)$ における， $\phi_{p}, \phi_{r}, \psi_{0}$ は，それぞれピー ク内部摩擦角, 残留内部摩擦角, 初期ダイレイタンシー
角， $B, C$ は材料定数である。これら解析に使用するパ ラメータは, 基本的には要素試験結果を基に決められ, ここでは，文献 16) を参考に密詰め豊浦砂に対応する, $\gamma_{d}=16.5 \mathrm{kN} / \mathrm{m}^{2}, E=15000 \mathrm{kN} / \mathrm{m}^{2}, v=0.3, \phi_{p}=45^{\circ}$, $\phi_{r}=35^{\circ}, \psi_{0}=20^{\circ}, B=C=0.5$ を採用した。.また，せん 断帯の幅は, Yoshida $5^{17)}$, Sakai $5^{18)}$ の結果より, 豊浦 砂の平均粒径の 20 倍となる $0.3 \mathrm{~cm}$ を採用した。図-2に 解析に使用した円形基礎，正方形基礎の有限要素メッ シュを示す。使用した要素は，アイソパラメトリック 3 次元 8 節点要素で, 解析は計算効率を考慮し動的緩和 法を用いた。 有限要素メッシュの節点数および要素数 は，計算効率を考え，対称性を利用して $1 / 4$ の領域を対 象とし，それぞれ円形基礎では 5244，4356，長方形基 礎では 6348，5324で，解析はアンカー基礎に相当す る節点に強制変位を与えることで行った。 なお, 境界 条件は, 地盤周囲を $x y$ 方向固定, 地盤底面を $z$ 方向固 定とした。本解析の詳細については文献 16) に示す.

\section{3. 実験および解析結果}

図-3 は， $D=3 \mathrm{~cm} ， 5 \mathrm{~cm} ， 7 \mathrm{~cm} ， 10 \mathrm{~cm}$ における円 形基礎, 正方形基礎の引抜き荷重と変位との関係を示 したものである。いずれの場合も荷重変化は，ピーク 值を示した後低下し，いわゆるひずみ軟化が見られる. 図-4 は， $D=5 \mathrm{~cm}, 10 \mathrm{~cm}$ における実験および解析に よる荷重と変位の関係を比較したものである. 本解析 では，比較的単純なひずみ軟化モデルを採用している ため, 解析と実験とでピーク荷重值の発生変位および 軟化の程度に差が見られるものの, ピーク荷重值はほ ぼ等しい值を示している。図-5 は, 円形基礎, 正方形 基礎における $D$ とピーク荷重值との関係を実験につい て示したものである. 各 $D$ における両基礎のピーク荷 重值を比較すると, いずれの $D$ においても正方形基礎 の方が高くなっている. また, 各 $D$ における正方形基 


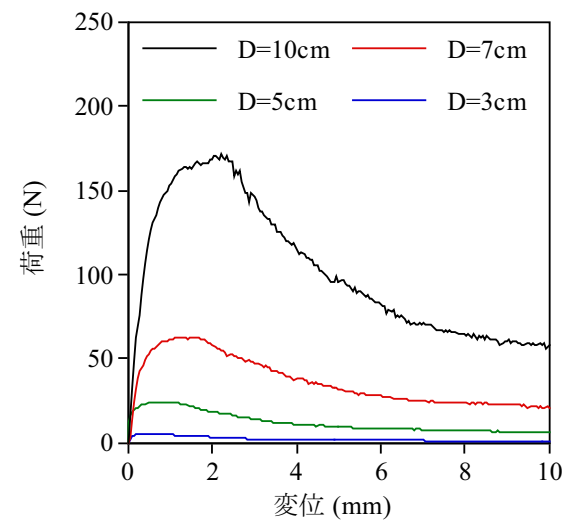

(a) 円形基礎

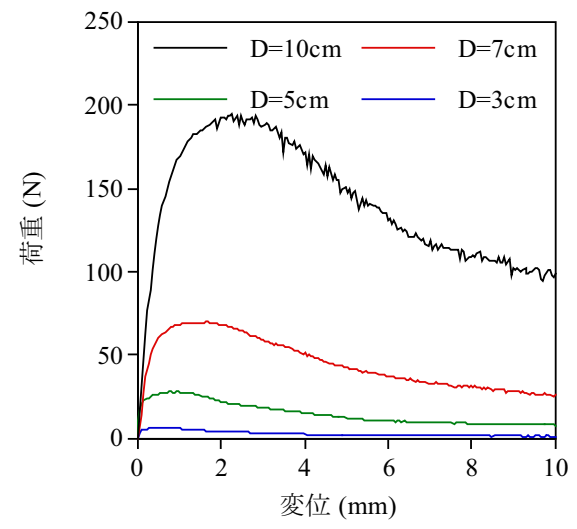

(b) 正方形基礎

図-3 実験による荷重一変位関係

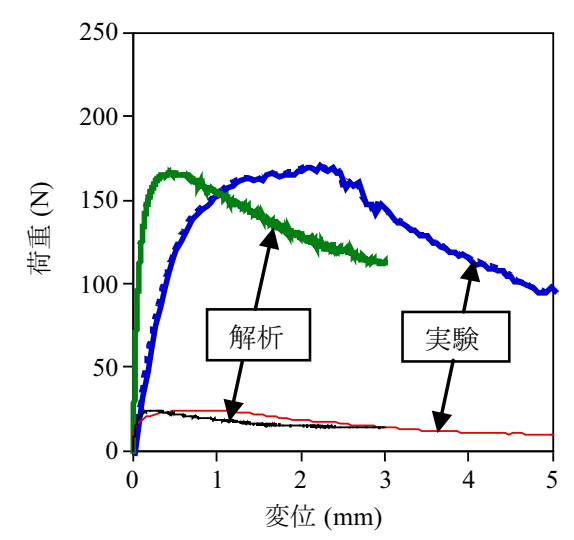

(a) 円形基礎

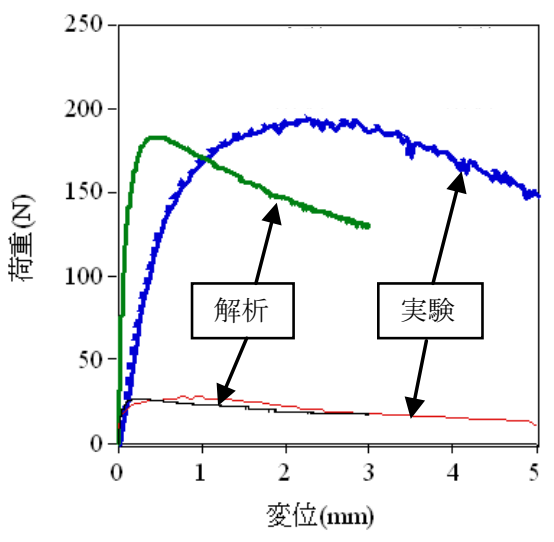

(b) 正方形基礎

図-4 有限要素解析と実験との比較

礎と円形基礎のピーク荷重值の差は， $D$ が大きくなる に従い大きくなる. 図-6は， 円形基礎，正方形基礎に おける地盤表面に現れた盛り上がりの状況を示したも のである. 地盤表面の盛り上がりの形状は, 円形基礎 では円形状に，正方形基礎では四隅が円弧となる形状 を示す. 図-7は, 両基礎について, 解析から求まった, 最大せん断ひずみ分布を示したものである. 地盤表面 での最大せん断ひずみ分布は, 円形基礎では円形の分 布を，正方形基礎は隅が円弧の形状をなす分布を示し， 解析結果は実験による観察結果とほぼ一致した結果を 示すと考えられる. また, 実験による地盤内のせん断 帯の発達方向 ${ }^{14)}$, および解析による最大せん断ひずみ 分布の集中する方向は, 水平面とおよそ $65^{\circ}$ の角度をな す. 表-1, 表-2 は, 正方形基礎と円形基礎のピーク荷 重値，並びに正方形基礎と円形基礎のピーク荷重值の 比を, 実験および解析について示したものである.い ずれの $D$ においても両基礎とも解析と実験のピーク荷 重值はほぼ一致している。同一 $D$ におけるピーク荷重 值は, 実験, 解析とも正方形基礎の方が高い值を示し,

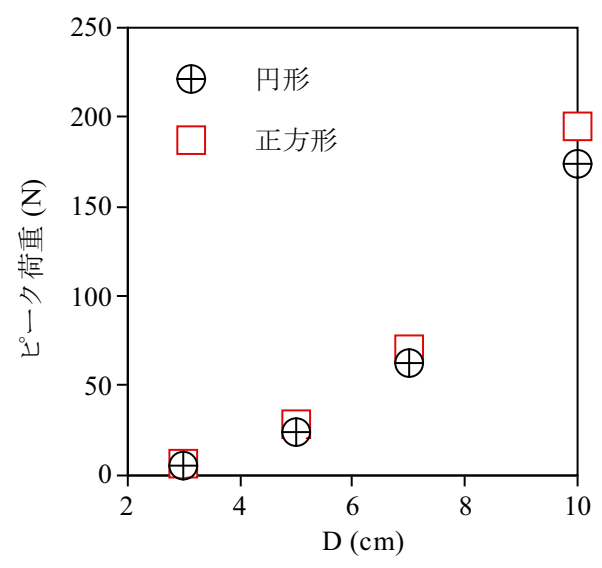

図-5 ピーク荷重と $D$ との関係

正方形基礎と円形基礎のピーク荷重值の差は， $D$ の増 加に伴い大きくなる. しかし, 正方形基礎と円形基礎 のピーク荷重值の比は, 1.10 から 1.14 程度と大きな差 は見られない。

図-8 は, 円形基礎および正方形基礎における $D$ と無 


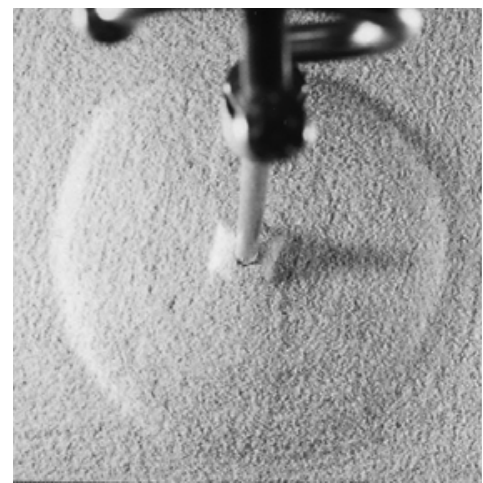

(a) 円形基礎

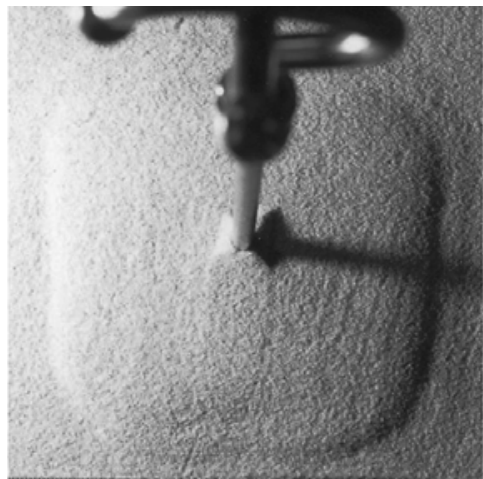

(b) 正方形基礎

図-6 地盤表面の盛り上がりの状況 $(D=3 \mathrm{~cm}$, 変位 $10 \mathrm{~mm})$

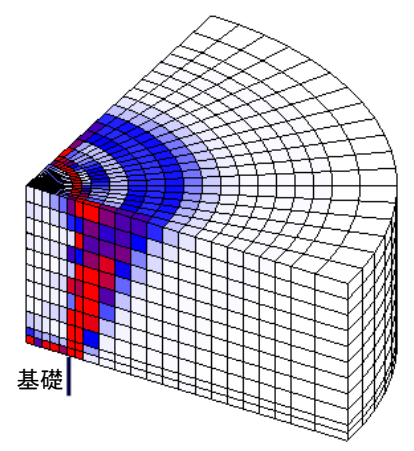

(a) 円形基礎

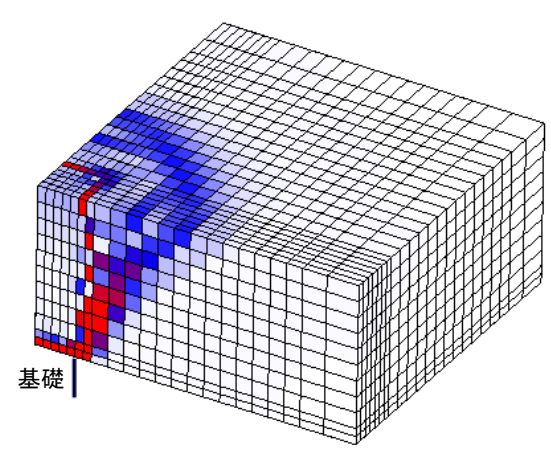

(b) 正方形基礎

$\max$ shear $(\%)$

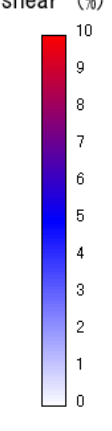

図-7 有限要素解析による最大せん断ひずみ分布 $(D=5 \mathrm{~cm}$, 変位 $3 \mathrm{~mm})$

表-1 実験結果のまとめ

\begin{tabular}{|c|c|c|c|c|c|}
\hline \multirow[b]{2}{*}{ アンカー幅 } & \multicolumn{2}{|c|}{ 円形 } & \multicolumn{2}{|c|}{ 正方形 } & \multirow{2}{*}{$\begin{array}{l}\text { ピーク荷重値の比 } \\
\text { (正方形 /円形) }\end{array}$} \\
\hline & ピーク荷重值 $(\mathrm{N})$ & ピーク無次元荷重值 & ピーク荷重值 $(\mathrm{N})$ & ピーク無次元荷重值 & \\
\hline$D=3 \mathrm{~cm}$ & 5.5 & 7.84 & 6.3 & 7.11 & 1.14 \\
\hline$D=5 \mathrm{~cm}$ & 24.5 & 7.67 & 28.0 & 6.77 & 1.14 \\
\hline$D=7 \mathrm{~cm}$ & 62.3 & 7.12 & 69.9 & 6.25 & 1.12 \\
\hline$D=10 \mathrm{~cm}$ & 174.4 & 6.75 & 195.2 & 5.95 & 1.12 \\
\hline
\end{tabular}

表-2 有限要素解析結果のまとめ

\begin{tabular}{c|c|c|c|c|c}
\hline & \multicolumn{2}{|c|}{ 円形 } & \multicolumn{2}{|c|}{ 正方形 } & ピーク荷重値の比 \\
\cline { 1 - 3 } アンカー幅 & ピーク荷重值 $(\mathrm{N})$ & ピーク無次元荷重值 & ピーク荷重值 $(\mathrm{N})$ & ピーク無次元荷重值 & \\
\hline$D=3 \mathrm{~cm}$ & 5.5 & 7.90 & 6.3 & 7.11 & 1.14 \\
$D=5 \mathrm{~cm}$ & 24.5 & 7.55 & 27.8 & 6.74 & 1.13 \\
$D=7 \mathrm{~cm}$ & 62.5 & 7.03 & 69.2 & 6.11 & 1.11 \\
$D=10 \mathrm{~cm}$ & 169.8 & 6.55 & 186.5 & 5.65 & 1.10 \\
$D=25 \mathrm{~cm}$ & 222.5 & 5.49 & 249.4 & 4.83 & 1.12 \\
\hline
\end{tabular}

次元ピーク荷重值 $\left(N_{p} ; P / \gamma_{d} h A, P:\right.$ ピーク引抜き荷 重値, $\gamma_{d}$ : 乾燥単位体積重量, $h$ : 地盤高さ, $A$ : 断面 積）との関係を示したものである.ここで用いる無次 元荷重值は, 一般にアンカーの相似則を評価する上で 用いられているものである ${ }^{19)}$. 同一 $D$ において $N_{p}$ を
比較すると，いずれの $D$ においても円形基礎の方が高 い值を示寸. $D$ の変化に伴う $N_{p}$ の変化を見ると, $D$ の 増加に伴い両基礎とも $N_{p}$ は低下し, いわゆるスケール 効果が認められる。 しかし, 両基礎の $D$ の増加に伴う $N_{p}$ の低下の程度に大きな違いは見られず, 両基礎のス 


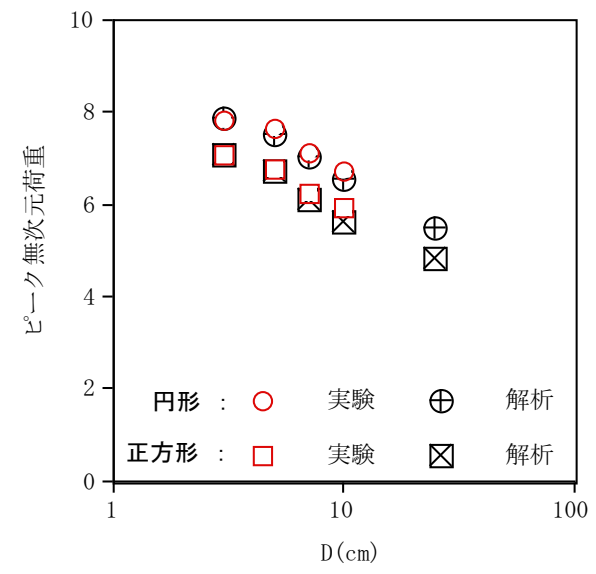

図-8 無次元ピーク荷重と $D$ との関係

ケール効果に大きな差はないものと考えられる.

\section{4. おわりに}

円形基礎および正方形基礎を用い，モデル実験およ び三次元有限要素解析の両面から，アンカー基礎の形 状の影響について検討を行った。 その結果，下記のこ とが明らかとなった。

（1）非関連流れ則を適用し，せん断帯・ひずみ軟化を 考慮に入れた 3 次元弾塑性有限要素解析により得 られたピーク荷重值および最大せん断ひずみ分布 は，実験により求まったピーク荷重值および破壊 面の発達状況と一致し, 本解析が実験を再現でき ることが明らかとなった。

（2）同一の $D$ におけるピーク荷重值は，表面積が大き い正方形基礎の方が大きくなるものの，ピーク無 次元荷重值は, 円形基礎の方が大きくなった.

（3）両基礎とも $D$ の増加に伴いピーク無次元荷重值は 低下し, スケール効果が認められたものの, 両基礎の スケール効果の程度に大きな差は見られなかった。 本解析では，ピーク強度までが弾性体，その後ひず み軟化するとした比較的単純な構成モデルを採用して いるため, 解析と実験とでピーク荷重值の発生変位お よび軟化の程度に差が見られたものと考えられる。今 後は, 実際の地盤での挙動をより良く表現できる硬化・ 軟化構成モデル9)を用いた 3 次元解析を実施したいと考 えている.

\section{参考文献}

1) Ball, A. : The resistance to breaking-out of mushroom foundations for pylons, Proc. 5th. Int. Conf. Soil Mech. Found. Eng., pp.569-576, 1961.

2) Matsuo, M. : Study on the uplift resistance of footing (1), Soils and Foundations, Vol.7, pp.1-37, 1967.

3) Dickin, E. D. : Uplift behavior of horizontal anchor plates in sand, ASCE, J. of Geotechnical Engineering, Vol.114, pp.1300-1317, 1988.

4) Sutherland, H. B. : Uplift resistance of soils, Geotechnique, Vol.38, pp.493-516, 1988.

5) Walters, J. V. and Thomas, J. N. : Shear zone development in granular materials, Proc. 4th. Int. Conf. on Numerical Method in Geomech., pp.263-274, 1982.

6) Tagaya, K., Tanaka, K. and Aboshi, H. : Application of finite element method to pullout resistance of buried anchor, Soils and Foundations, Vol.23, pp.91-104, 1983.

7) Borst, R. D. and Vermeer, P. A. : Possibilities and limitations of finite elements for limit analysis, Geotechnique, Vol.34, pp.199-210, 1984.

8) Rowe, R. K. and Davis, E. H. : The behavior of anchor plates in sand, Geotechnique, Vol.32, pp.25-41, 1982.

9) Sakai, T. and Tanaka, T. : Experimental and numerical study of uplift behavior of shallow circular anchor in two-layered sand, ASCE, J. of Geotechnical and Geoenvironmental Engineering, Vol.133, No.4, pp.469-477, 2007.

10) 岡安崇史, 橋口公一, 尾崎利行, 竹添亮 : アンカー引抜 時の地盤の変形挙動に関する弾塑性有限要素解析, 応用 力学論文集, Vol.3, pp.11-20, 2003.

11) Sakai, T. and Tanaka, T. : Scale effect of a shallow circular anchor in dense sand, Soils and Foundations, Vol.38, pp.9399, 1998.

12) Ovesen, N. K. : Centrifuge tests of the uplift capacity of anchors, Proc. 7th. European Conf. Soil Mech. and Found. Eng., Vol.4, pp.318-323, 1981.

13) Meyerhof, G. G. and Adams, J. I. : The ultimate uplift capacity of foundations, Canadian Geotechnical Journal, Vol.5, pp.225-244, 1968.

14）酒井俊典, 田中忠次, 阪上最一: 傾斜砂地盤におけるアン カー基礎の引揚げについて, 地盤工学会誌, Vol.53, No.7, pp.20-22, 2005.

15) 池田清宏, 山川優樹, 森田耕平, 堀本壮亮, 尾崎利行 : 逆 $\mathrm{T}$ 型基礎の引揚支持力評価への弾塑性有限要素解析の 適用性に関寸る考察，土木学会論文集 C, Vol.63，No.1， pp.1-12, 2007.

16) 田中忠次, 鵜飼恵三, 河邑眞, 阪上最一, 大津宏康 : 地 盤の三次元弾塑性有限要素解析, pp.84-86, 丸善, 1998.

17) Yoshida, F., Tatsuoka, F., Siddiquee, M. S. A., Kamegai, T. and Park, C. S. : Shear banding in sands observed in plane strain compression, Localisation and Bifurcation Theory for Soils and Rocks, pp.165-179, 1993.

18) Sakai, T., Erizal and Tanaka, T. : Particle size effect of anchor problem with granular materials, Proc. 4th European Conf. Numerical Methods in Geotechnical Engineering, pp.191-200, 1998.

19) Lindsay, J. A.: The use of physical models in design, Design Parameters in Geotechnical Engineering, BGS, London, Vol.4, pp.324-326, 1980. 


\title{
UPLIFT BEHAVIOR OF CIRCULAR AND SQUARE ANCHOR FOUNDATIONS IN DENSE SAND
}

\author{
Toshinori SAKAI and Tadatsugu TANAKA
}

This study evaluated an uplift behavior of circular and square anchor foundations in dense Toyoura sand, by comparing a model test with 3D FE analysis. The model tests were performed by taking the value of $h / D$ as two. The 3D analysis was an elasto-plastic model in which progressive failure with shear band effect was introduced into the constitutive equation. The 3D analysis was able to predict the uplift behavior in both circular and square anchor foundations. The uplift resistance in circular anchor foundation was smaller than in square anchor foundation in case of having same $D$. The scale effect was recognized and the degree of the scale effect was similar in both anchor foundations. 